\title{
Communicative competence enhancement
}

\author{
Irina I. Klimova - Natalia E. Sharabarina - Elena A. Tikhova - \\ Sviatlana A. Dubinka
}

DOI: 10.18355/XL.2018.11.01XL.07

\begin{abstract}
The article deals with modern challenges in teaching a foreign language at a higher educational institution, connected with the changes taking place in the system of higher education in the world. The characteristics of three generations of universities are given, the main emphasis being on the development of the $3 \mathrm{G}$ university as the center of an innovative cluster. The authors also focus attention on the importance of forming entrepreneurial competencies among university graduates and the growing need to learn English as a language of intercultural and business communication, hence the use of electronic, distance and mixed instruction for a better quality of foreign language competency in higher education. Modern challenges in language education relate to the creation of digital educational content on the basis of training courses, the introduction of modern information technologies in the educational process, proactive scientific developments based on advanced foreign experience.

Key words: entrepreneurial competence, $3 \mathrm{G}$ university, intercultural and business communication, business incubators, innovative cluster
\end{abstract}

\section{Introduction}

Global changes taking place in the economic, political, and social spheres directly concern the education system in general and higher education in particular. Higher education institutions or universities change fundamentally, moving from the model of a scientific university to the level that has been called the third generation university or $3 \mathrm{G}$. This change is caused by two main driving forces. The first is that leading university that lack the means to continue advanced scientific research are looking for alternative funding since the cost of such research exceeds the state budget allocated to science. As a result, the world's leading universities are eager to collaborate with technology-based enterprises. At the heart of the second driving force lies the fact that technologically-driven enterprises tend to stop conducting fundamental research. Instead they seek to cooperate with high-ranking universities to work together on basic research projects that they believe will be decisive in their future competitiveness. The rest of the driving forces include:

- Increased mobility among students, promising scientists in the context of globalization, hence the three-dimensional global competition among universities: students - scientific and pedagogical staff - corporations;

- Priority from the state to business incubators in higher education institutions;

- studies in the interdisciplinary area;

- the growth of autonomous research institutes funded by the state.

\section{LiteratureReview}

Despite the existence of numerous scientific studies on communicative competence enhancement, there is no complex and systematic analysis of communicative competence development under the condition of moving from the model of a scientific university to the third generation university or $3 \mathrm{G}$. It seems promising to consider modern information technologies' integration into upgraded teaching and learning environment. We examine the characteristics of three 
generations of universities to reveal the concept of the higher-quality formation of foreign-language competence in higher education. We investigate mechanisms to instill students with necessary qualities, skills, knowledge, and confidence to conduct the entrepreneurial activity. There is a need for pedagogical practice in the scientific and methodological substantiation of the essence and mechanisms of the formation of entrepreneurial competencies in university students.

Under entrepreneurial competencies, we consider a range of skills in which a person has the authority, knowledge, experience to conduct successful business activities; as well as behaviors demonstrated in the process of effectively performing business tasks.

Currently, there is no single list of entrepreneurial competencies. The first attempt to study them was made during a large-scale intercultural study conducted by the United States Agency for International Development (USAID) (McClelland, 1973; Spencer, L. \& Spencer, 1993). As a result, a set of competencies for successful entrepreneurs was compiled (Revin \& Tsybulevskaya, 2015):

1. Competence of achievement (initiative, sees and uses opportunities, care for the high quality of work, obligations under the contract, focus on efficiency). solving).

2.Competence thinking and problem solving (systematic planning, problem-

3. Directness and self-control (perseverance, self-control).

4. Orientation to others (recognition of the importance of business relationships).

The list of competencies is defined by the new generation of the Federal State Educational Standard of Higher Education, but universities face a problem of forming the same competence by different disciplines, and on the way out is the problem of finding a mechanism for verifying all competences laid down in the curriculum.

\section{Results and Discussion}

One of the main founders of 3G-university is Professor Vissema (2009), who believes that in a competitive, interdisciplinary nature of fundamental and applied research, this model of the university is the only one in which universities can remain at the forefront of scientific activity.

$3 \mathrm{G}$ University is the center of an innovative cluster that manages results of intellectual activity, stimulates the creation of an entrepreneurial ecosystem and consists of research institutes, small enterprises, and financial and other institutions that provide various services to small businesses and start-ups. In a modern economy that is a "knowledge economy," 3G universities are becoming instruments of economic growth that are closely related to public and commercial sectors and financed by technology transfer. Morden trends require the formation and development of competencies which will meet the requirements of technology-driven society. Thus a model of forming entrepreneurial competencies should be introduced. To develop the model we need to interpret chronologically the transition from the 1 st university to the 3rd generation university keeping in mind their characteristics such as purpose, role in learning, method, and training, orientation, language, organization and management (Table 1).

Table 1: Characteristics of three generations of universities

\begin{tabular}{llll}
\hline & 1st generation & 2nd generation & 3rd generation \\
\hline Purpose & Training & Training + research & Training + research \\
& activities & $\begin{array}{l}\text { activities + use of } \\
\text { practical knowledge }\end{array}$
\end{tabular}

\begin{tabular}{llll}
\hline Role in Conformance & Identifying & Improving Learning \\
\hline
\end{tabular}




\begin{tabular}{lllll}
\hline Learning & & \multicolumn{2}{l}{ Learning Content } & \multicolumn{2}{l}{ Effectiveness } \\
\hline Method & Educational & $\begin{array}{l}\text { Modern science, } \\
\text { monodisciplinary } \\
\text { area of knowledge }\end{array}$ & $\begin{array}{l}\text { Modern science, } \\
\text { interdisciplinary } \\
\text { area of knowledge }\end{array}$ \\
\hline Training & Specialists & $\begin{array}{l}\text { Specialists } \\
\text { Scientists }\end{array}$ & $\begin{array}{l}\text { Specialists } \\
\text { Scientists } \\
\text { Entrepreneurs }\end{array}$ \\
\hline Orientation & Universal & National & Global \\
\hline Language & Latin Language & National languages & English \\
\hline Organization & $\begin{array}{l}\text { Groups, faculties, } \\
\text { universities }\end{array}$ & Faculties & $\begin{array}{l}\text { University research } \\
\text { institutes }\end{array}$ \\
\hline Management & $\begin{array}{l}\text { Rector of the } \\
\text { University }\end{array}$ & $\begin{array}{l}\text { Scientific } \\
\text { pedagogical } \\
\text { (part-time) }\end{array}$ & and & Proffessional \\
& management \\
\hline
\end{tabular}

As a result, universities increasingly become system integrators of major processes of technological entrepreneurship. Universities actively unify human and financial capital flows. Historically, the main innovation zones were formed around leading universities. Examples of this exist in many countries, including Russia with its "5/100" program, which develops industrial and entrepreneurial environment across universities. Therefore, within the framework of the national technology initiative (STI) universities also have a key role.

In our opinion, the disparate worlds of academic and industrial research are increasingly intertwined. If prior a university had to receive competences from the market in the field of development prospects: whom to teach, what technologies to develop, what research to conduct, now Russian universities should take an example from world leaders in the field of education. To implement STI, new supporting infrastructure is needed that would help commercialize innovation. This intersection can be most effectively provided by the university through the system integration and consolidation of processes that take place in scientific research and R\&D. According to the World Intellectual Property Organization, China, Korea, and several other countries have formed their own model to solve the problem. In those countries, universities or, to a lesser extent, private commercial research organizations become main providers of start-ups and commercial, intellectual property. Chinese universities, for example, are leading in the number of patents in the field of robotics. American universities are not far behind with 200-300 patents per year. And their patents are almost always associated with providing a technological quality solution. By "supplying" intellectual property, universities today are comparable to leading corporations. This conveyor is formed: knowledge passes from scientific research to patents, then to licenses, then to the commercial environment. Universities become a platform where leaders - leading professors - can realize their potential with maximum impact. This gives rise to competition between universities. Those who tout only educational or scientific resources are falling behind. There is a gradual increase in the level of complexity and value that university as a "corporation of knowledge" brings to the intellectual process.

Modern stratification of universities falls into three typical models: 1.0 (3 levels of education, talent search); 2.0 (research competence, consulting and service); 3.0 (adding entrepreneurial competencies and the possibility of creating start-ups) raise the issue of what competencies a future entrepreneur should possess after graduating from an educational institution.

On the bases of data collected by the analysis of scientific literature, we developed the model of forming entrepreneurial competencies which stipulates the 
following sequence: theoretical knowledge acquisition, development of skills and abilities, sustainable personal qualities, competencies (Fig. 1).

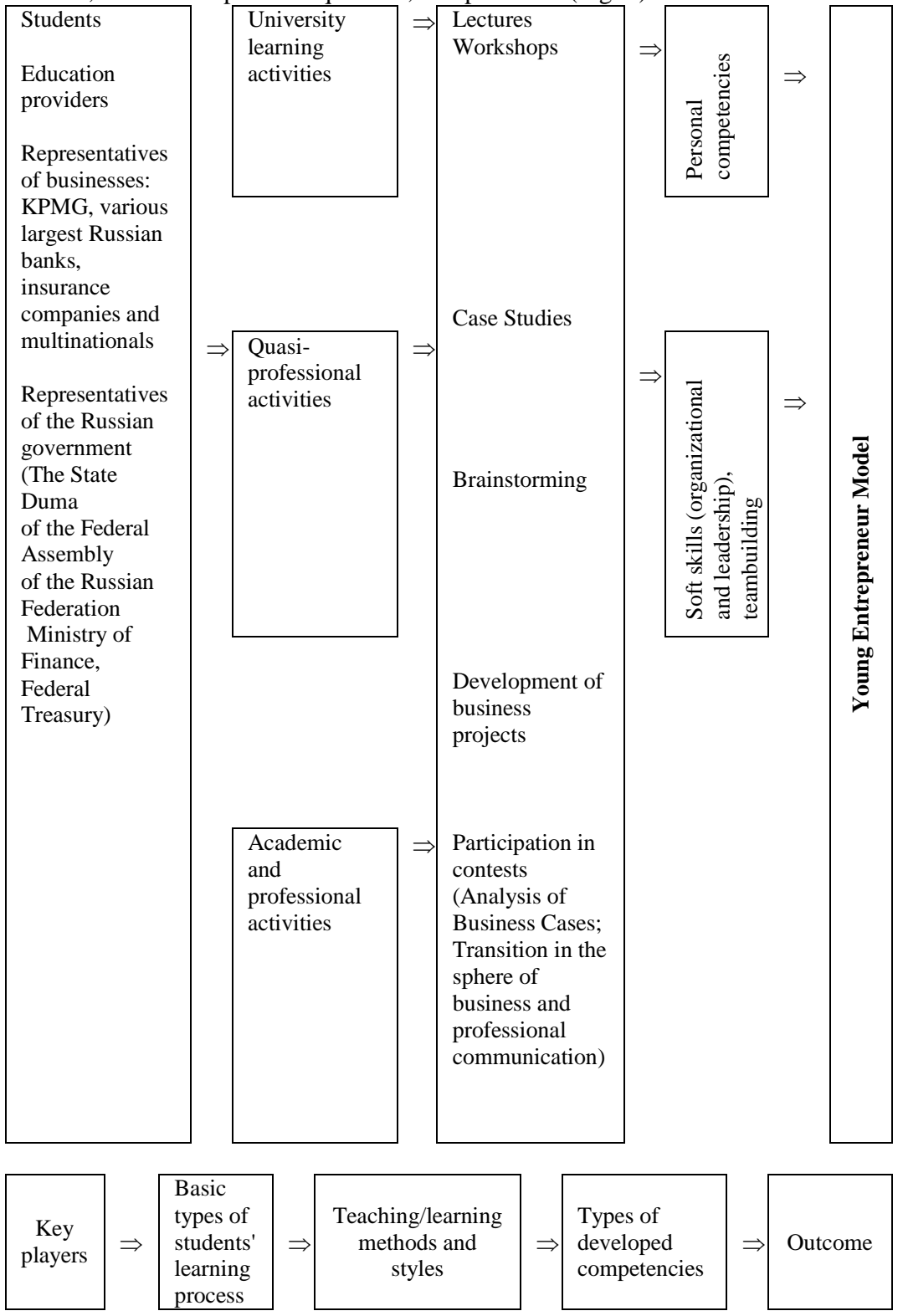

Figure 1: Model of development students' entrepreneural competencies

In the context of implementing the concept of modernizing modern education, e-learning, distance learning and blended learning are important for the higher-quality formation of foreign-language competence in higher education. 
In 2013 Financial University under the Government of the Russian Federation provided students and teachers with Rosetta stone Advantage online language learning program. Students and teachers had a chance to work in computer language laboratories equipped with hardware, headphones, projector and the software Rosetta Stone Advantage. Special courses were organized for the teachers to provide them with multiple instruments to manage class work in a motivating and effective way. More than 50 teachers were trained to work in that system.

Total immersion in language learning by means of the program Rosetta Stone Advantage allowed enhancing discursive, foreign language, sociolinguistic competencies, making progress in four types of language skills: speaking, reading, listening and writing. Students had the opportunity to broaden their horizons with lessons based on real-life videos, professional situations they would like to master: participation in discussions on various topics with clients or business partners; participation in discussions on topics from specialized content, for example, Accounting, Finance, Sales, Marketing, Negotiations, meetings and effective presentations. Figure 1 shows the range of language skills trained by means of Rosetta Stone Advantage language learning program.

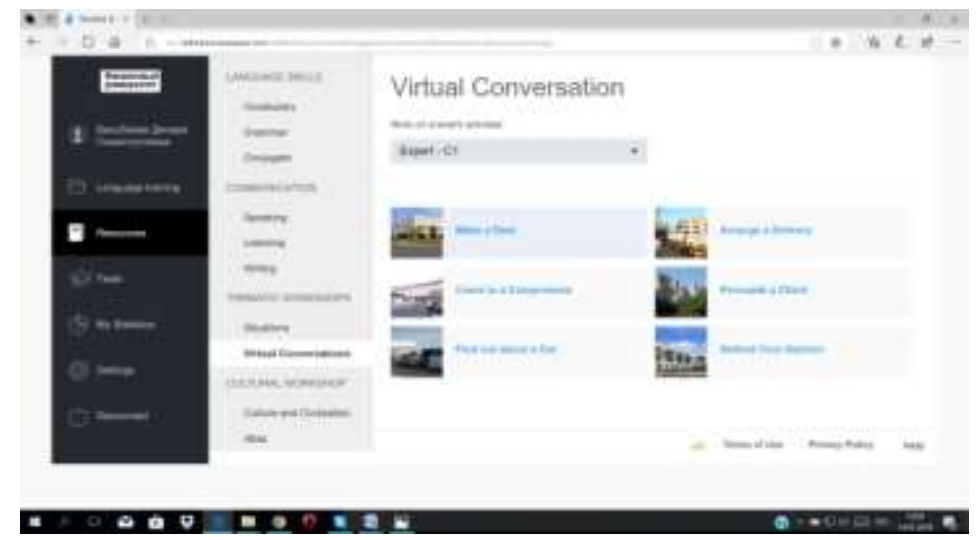

\section{Figure 2: Language skills trained by means of Rosetta Stone Advantage language learning program}

In blended learning, as well as in the traditional one, it is envisaged to conduct classroom classes in accordance with the Federal-State Educational Standard of Higher Education and curricula in the areas of training. But the main emphasis is put on the use of information and communication technologies and elearning (Vasbieva \& Klimova, 2015). The model of blended learning, which is the integration and complementation of traditional and e-learning (face-to-face and elearning), based on educational classical and Internet resources, the availability of the appropriate PC toolkit, gadgets, smartphones, is actively used in teaching the professional foreign language of the students of the Financial-University.

Main advantages of the blended learning model are:

- the focus of a person-oriented approach;

- the flexibility of the educational process;

- the openness of the educational process;

- development of an ability to independently and efficiently plan and organize their training activities (time management);

- increase in students' motivation; 
- receiving instant feedback from both teachers and students;

activity;

- transparency and objectivity of evaluation of the student's learning

- the possibility of adjusting the results;

- a student is an active participant in the educational process;

- Improvement of the effectiveness of the learning process.

In recent decades, the market for alternative education or the so-called mass open online courses MOOCs (Massive Open Online Courses) is developing most rapidly, in most cases free and with a huge range of disciplines available and able to compete with university programs. Great examples of open online courses are:

- Edx is a global online education project for world education leaders (MIT, Harvard).

- Coursera - project in the field of mass online education of Stanford University (free online courses); more than 1800 courses and more than 24 million registered users around the world; simplified navigation on the platform; ability to search by skills; the formation of certain skills in the process of passing this or that course.

BIC).

- eClass - a search engine for over 30,000 online courses (1000 in Russian,

The surest factor in accelerating the development of globalization is the spread of English. Obvious was the need to improve teaching methods and development of objective criteria that make it possible to learn the language more effectively. English, being the second most popular after Chinese, has really advanced far ahead on the way to gaining the status of an international language, and, therefore, actively contributes to the process of globalization. "More and more we are faced with the situation when modern information technologies, including educational ones, are based entirely on the material of the English language." The need for learning English increases with the popularity of digital educational resources. In this regard, in the study of English, relevance is acquired by mobile applications, electronic textbooks, podcasts, videos, programs, virtual laboratories and educational platforms for tutoring. The appearance of information technology allows training personalization in terms of pace and depth of a course. Such a differentiated approach gives a great positive result because it creates conditions to enable students' success giving them positivity and increasing their educational motivation.

\section{Conclusion}

Thus the study has highlighted modern challenges in language education which can be presented as follows:

- Globalization of the higher education system and knowledge of English as an international language of intercultural and business communication.

Creation of digital educational content on the basis of training courses for work in the electronic information and educational environment.

- Introduction of modern information technologies in the educational process, and initiative scientific developments based on advanced foreign experience.

- Entrepreneurship as a result of the formation of professional competencies among students and the perspective of the development of the university teacher.

We suggest taking into account all these obstacles English teachers could face enhancing students' communicative competence. Research data and theoretical considerations of the problem concerning moving from the model of a scientific university to $3 \mathrm{G}$ discussed in this study can be applied by EFL teachers developing communicative competence in the modern learning environment. 


\section{Acknowledgments}

The work is performed according to the Program of Development of Federal StateFunded Educational Institution of Higher Education "Financial University under the Government of the Russian Federation" for 2020.

\section{Bibliographic references}

KALUGINA, O. 2011. Development of Communicative Competence. Financial Research Institute. Financial Research, n.4, pp. 179-188. ISSN 2075-1990.

KALUGINA, O. 2016. The Assessment of Intercultural Communicative Competence. In: Science Review: Humanities Research, n. 9, pp. 55-58. ISSN 2226-0234.

KALUGINA, O. 2015. The Formation of Professional and Communicative Competency by Competency-Oriented Exercises (From the Experience of Teaching in a Non-Linguistic Institute of Higher Education). In: Philological Sciences. Issues of Theory and Practice, vol. 10, n. 52, pp. 103-106. ISSN: 1997-2911.

KALUGINA, O.A. 2016. Development of students' professional communicative competence in an economic higher school. In: XLinguae, vol. 9, n. 4, pp: $37-45$. ISSN 1337-8393.

McCLELLAND, D.C. 1973. Testing for competence rather than for "Intelligence". American Psychologist, vol. 28, n. 1, pp. 423-447. ISSN 0003-066X.

REVIN, I.A. - TSYBULEVSKAYA, D.L. 2015. Development of students' entrepreneurial competencies at technical higher school. Modern problems of science and education, vol. 2, n. 1. Available online: https://www.scienceeducation.ru/ru/article/view?id=19415

SPENCER, L.M. - SPENCER, L.M. 1993. Competence at Work: Models for Superior Performance. New York: John Willey \& Sons. 372 p. ISBN 9780471548096

VASBIEVA, D.G. - KALUGINA, O.A. 2014. Formation of foreign language intercultural competence as the component of professional communicative competence of Economics major students. In: Science Review: Humanities Research, n. 5, pp. 15-25. ISSN 2226-0234.

VASBIEVA, D.G. - KALUGINA, O.A. 2016. An Analysis of Students' Intercultural Competence Levels in a Non-Linguistic Higher School. In: XLinguae, vol. 9, n. 3, pp.58-69. ISSN 1337-8393.

VASBIEVA, D. G. - KLIMOVA, I. I. 2015. Transformational potential of blended learning to personalize foreign language teaching in a non-linguistic higher school. XLinguae, vol. 8, n. 1, pp. 2-10.

WISSEMA, J.G. 2009. Towards the Third Generation University: Managing the University in Transition. Cheltenham: Edward Edgar Publishing. 252 p. ISBN 978-184844-216-0.

Words: 2801

Characters: 21360 (11,87 standard pages)

Prof. Irina I. Klimova, PhD

Department of Foreign Languages

Financial University under the Government of the Russian Federation

Leningradsky prospect 49

125993 Moscow

Russia

IIKlimova@fa.ru

Assoc. Prof. Natalia E. Sharabarina, PhD

XLinguae, Volume 11 Issue 1XL, January 2018, ISSN 1337-8384, eISSN 2453-711X 
Senior Lecturer Elena Tikhova

Department of English Language

Lomonosov Moscow State University

Business School

Lenin Hills 1-52, 119991Moscow

Russia

shaned@inbox.ru

e.tikhova@mail.ru

Prof. Sviatlana A. Dubinka, PhD

Department of English for Economics

Belorusian State University

4, Nezavisimosti avenue

220030 Minsk

Republic of Belarus

svetlanadubinko@gmail.com 